\title{
Using T3 For Treatment of Hypothyroidism - What the Evidence Say?
}

\author{
Vismay Naik* \\ Ashirvad Heart and Diabetes Centre, India
}

Submission: March 01, 2017; Published: June 27, 2017

*Corresponding author: Vismay Naik, MD, MRCP (London), Ashirvad Heart and Diabetes Centre, Botad, Gujarat, India, Email: vismay101@gmail.com

\section{Introduction}

Hypothyroidism is due to the primary disease of the thyroid or secondary to hypothalamic- pituitary disease [1]. Primary hypothyroidism is the most common endocrine disorder throughout the world. Traditionally we have been using levothyroxine in the treatment of hypothyroidism. However, there have been reports of persisting symptoms of hypothyroidism in $5-10 \%$ of levothyroxine treated hypothyroid patients

with normal serum thyrotrophin (TSH) [2]. Physiologically levothyronine is the active form, so treating the patient with the active form has been considered optimum treatment. This study is aimed at reviewing the literature on using T3 in treatment of hypothyroidism either alone or in combination with T4. By the end of this study we hope to answer the question, if the use of T3 is a suitable treatment option.

\section{Treatment Strategies of Hypothyroidism}

The objectives of management of hypothyroidism are to reverse clinical progression, correct metabolic abnormalities, [3] and reduction of goiter size in patients with autoimmune Hashimoto's thyroiditis [4]. This can be achieved by 3 different strategies:

a. Standard treatment with a daily dose levothyroxine (T4) in order to reach an age adjusted TSH target [5]. The dose has to be titrated periodically [3].

b. Triiodothyronine (T3) monotherapy is the biological active form. It has theoretical benefits, main drawback being its short half-life [6]

c. T4 and T3 combination therapy in patients with defects in deiodinase enzymes, however there is debate [6] (Table 1).

Table 1: T4 and T3 combination therapy.

\begin{tabular}{|c|c|c|c|}
\hline & Treatment with T4 only & Treatment with T3 only & Treatment with both $\mathrm{T} 3$ and $\mathrm{T} 4$ \\
\hline Rationale & $\begin{array}{l}\text { Normal thyroid secretes both } \\
\text { T3 and T4., but for T3 } 80 \% \text { is by } \\
\text { peripheral conversion }\end{array}$ & $\begin{array}{c}\text { Treatment with biological active } \\
\text { form }\end{array}$ & Physiological as in body \\
\hline Advantages & $\begin{array}{l}\text { Easily available preparation, once } \\
\text { daily dosing, Ft4 is same for all } \\
\text { age groups, dose adjustment easy } \\
\text { with TSH adjustment }\end{array}$ & $\begin{array}{c}\text { Metabolic benefits, theoretical } \\
\text { advantage, }\end{array}$ & $\begin{array}{l}\text { A combination of levothyroxine } \\
\text { (T4) with liothyronine (T3) } \\
\text { improved quality of life, mood, } \\
\text { and psychometric performance, } \\
\text { compared with thyroxine } \\
\text { treatment alone. }\end{array}$ \\
\hline Drawback & $\begin{array}{l}\text { Imbalance of hormones at the } \\
\text { peripheral level, pituitary secreted } \\
\text { TSH may not reflect what happens } \\
\text { in target tissues, therefore, serum } \\
\text { TSH may not be an appropriate } \\
\text { indicator of peripheral tissue } \\
\text { euthyroidism }\end{array}$ & Short half life, multiple dosing & $\begin{array}{l}\text { High incidence of adverse } \\
\text { symptoms (palpitation, irritability, } \\
\text { dizziness, nervousness and } \\
\text { tremors) during the treatment } \\
\text { of hypothyroidism with the } \\
\text { combined T4/T3 preparation. } \\
\text { Insufficient evidence to show that } \\
\text { combination therapy is superior } \\
\text { to L-T4 monotherapy. }\end{array}$ \\
\hline
\end{tabular}




\section{Rationale for Using T3}

Within the human body thyroxine (T4) is produced only in the thyroid gland where as $20 \%$ of Triiodothyronine (T3) is secreted by the thyroid gland and $80 \%$ generated in extra thyroidal tissue by deiodination of T4 [2]. The biological effects of thyroid hormone are mediated through the interaction of T3 with its receptors. T4 is devoid of intrinsic activity. Hence, replacement therapy with LT4 relies entirely on deiodination step. So its benefits include

a. T3 is more physiological and to achieve serum T3 levels within a normal range a high to higher than normal T4 serum level is required.

b. It bypasses the deiodination step

c. There is direct delivery of the bioactive drug to the target organs and tissues.

d. Substrate requirement in D2-expressing tissues will not be necessary.

e. Thrice daily administration provide comparable TSH suppression [7].

f. There are comparable effects on cardiovascular function, glucose homeostasis and quality-of-life endpoints.

g. It provides increased hormonal signal to the liver, with have improved weight loss, reduced LDL-cholesterol, and increased SHBG.

\section{Drawbacks of T3 Therapy}

I. Not well regulated tissue and time-specific T3 production.

II. Multiple daily dosing or sustained release preparation to maintain serum T3 levels due to the shorter half-life

III. Supra normal serum T3, required to normalize serum TSH and hypothalamic TRH expression, may lead to relative hyperthyroidism in some tissues [8]

IV. The circulating and tissue levels of T3 is dependent on the pharmacokinetic characteristics of administered LT3, due to lack of $\mathrm{T} 4$ as a reservoir of substrate [9]

V. No available data on the long-term effects on bone and mineral metabolism, safety profile and cost- effectiveness and sustainability of the weight and lipid profile change. [10]

\section{Evidence for Therapeutic Benefits of T3 Monotherapy Over T4}

There is a paucity of data to support the use of T3. However, in some specific situations it may provide some benefit

a) A subset of hypothyroid patients with specific polymorphism in type 2 Deiodinase or who are athyreotic [2], these patients remain symptomatic despite normal T4 \& TSH level. b) Thyroid cancer patients undergoing radioiodineimaging are temporarily treated with $\mathrm{T} 3$ for three to four weeks until T4 is washed out, to shorten their period of hypothyroidism [11].

c) T3 monotherapy has been shown to have metabolic benefits with improvement in weight, LDL cholesterol [10], mood well being and psychometric functioning [12] as well as being better tolerated in high risk groups with dyslipidemia and obesity.

d) A double-blind randomized cross-over study demonstrated that as compared to LT4, an equivalent degree of serum TSH suppression can be achieved with LT3 at a ratio $(\mathrm{lg} / \mathrm{lg})$ of $1: 3$ when administered as a thricedaily regimen [13]. With this regimen the serum levels of T3 were significantly higher than the ones achieved with LT4 therapy, while serum TSH remained stable throughout the 24 hours [7]. In this study, no adverse events were recorded, the two treatments were also equivalent with respect to cardiovascular function and glucose homeostasis. Patients in the T3 group experienced more weight loss, a better decrease in LDL-cholesterol, and a $22.3 \%$ increase in SHBG, compared with LT4 therapy [7]. Serum TSH responses were similar in the LT3 and LT4 groups after performing TRH stimulation test, suggesting that metabolic differences were mediated peripherally and not at the pituitary gland level.

However, this treatment was cumbersome and required multiple adjustments, an average of 180 days to achieve a target serum TSH on a stable dose of replacement therapy.

The LT3 monotherapy appears more favorable for patients affected by dyslipidemia and obesity, but at the present time there is not sufficient evidence to suggest that it is superior to the standard LT4 therapy, particularly because of the necessity of strict compliance to the regimen and the timing of the drug administration, the risk of over- or under dosing, and the risk of cardiac and skeletal toxicity. Further studies in the form of long-term, randomized, controlled trials of sustained release formulation of $\mathrm{T} 3$ are required.

\section{Evidence of Therapeutic Benefits of T3 And T4 Over T4}

In recent years much interest has been shown in the use of T4-T3 combinations in the treatment of hypothyroidism, in comparison with T4 monotherapy [12].

The first trial was conducted by Bunevicius etal. [14], in which 33 patients received either levothyroxine or levothyroxine and liothyronine for 5 weeks then switched to the other treatment in a randomised, double-blinded cross-over trial. They found that when patients were taking the combination, they scored better on neuropsychological tasks, and also that their psychological state improved [14]. These findings have not, however, been universally replicated [12]. 
Grozinsky-Glasberg et al. [15] conducted a meta-analysis of 11 randomised trials published between 1999 and 2005. They found no difference in the effectiveness of T4-T3 combination therapy over T4 monotherapy in terms of: bodily pain; depression; anxiety; fatigue; quality of life; body weight; total serum cholesterol or triglyceride levels.

Nygaard et al. [16] subsequently conducted a double-blind, randomised cross- over trial in which they ensured that patients with autoimmune thyroiditis had a stable TSH for 6 months prior to the study, and maintained a stable TSH level during the study. They did identify an improvement in quality of life and depression scores with combination therapy. Interestingly, they also found patients preferred the combination therapy over levothyroxine monotherapy.

A patient preference for combination therapy over has been found in a number of studies [17]. It is estimated that half of patients prefer combination therapy [18]. The preference of patients for combination therapy is demonstrated despite the absence of demonstrable clinical benefits [19]. Michaelsson et al. [20] found that a number of patients in Denmark are choosing to take combinations of T4 and T3 themselves despite guidelines that suggest T3 should only be used experimentally [18].

\section{Current Guidelines - Treatment of Hypothyroidism}

Based on the conflicting results of benefits from RCTs comparing combination therapy (LT4 and LT3) with LT4 monotherapy and a lack of long term outcome data, the American Thyroid Association (ATA) recommend against the routine use of combination therapy with LT4 and LT3 as a form of thyroid replacement in patients with primary hypothyroidism. Superiority of combination therapy over monotherapy with LT4 lacks consistent strong evidence [21].

The ATA recommends against the routine use of LT3 monotherapy due to insufficient evidence to suggest LT3 monotherapy is a safe and efficacious treatment in hypothyroidism including hypothyroid patients with obesity and dyslipidemia. Long term RCTs with sustained release formulation of T3 are needed before considering routine use of LT3.

\section{Conclusion}

Literature review suggests that there is theoretical benefit of $\mathrm{T} 3$ in treatment of hypothyroidism however, for it to be in routine use multiple long term studies are needed. Combination therapy with T3 and T4 has more clinical credits to it than T3 alone. But still the data is not sufficient for it to be introduced in the guideline for management of hypothyroidism. In near future may be we have more studies, more data so that we can start using T3 in our patients and they get the necessary benefit.

\section{References}

1. Kumar P, Clark M (2009) Clinical Medicine ( $9^{\text {th }}$ edn).
2. Wiersinga W, Duntas L, Fadeyev V, Nygaard B, Vanderpump MP (2012) 2012 ETA Guidelines: The Use of L-T4+ L-T3 in the Treatment of Hypothyroidism. Eur Thyroid J 1(2): 55-71.

3. Lazarus JH, Premawardhana LD (2006) Management of thyroid disorders. Postgrad Med J 82(971): 552-558.

4. Hansen JM, Feldt-Rasmussen U, Hansen BM, Hansen BM, HøierMadsen M (1991) Influence of thyroxine treatment on thyroid size and anti-thyroid peroxidase antibodies in Hashimoto's thyroiditis. Clin Endocrinol (Oxf) 35(3): 235-238.

5. Donnan PT, Leese GP, Murphy MJ, Vadiveloo T (2013) Age- and genderspecific TSH reference intervals in people with no obvious thyroid disease in Tayside, Scotland: the Thyroid Epidemiology, Audit, and Research Study (TEARS). J Clin Endocrinol Metab 98(3): 1147-1153.

6. Duntas L, Fadeyev V, Nygaard B, Wiersinga WM, Vanderpump MPJ (2012) ETA guidelines: the use of L-T4 + L-T3 in the treatment of hypothyroidism. Eur Thyroid J 1: 55-71.

7. Celi FS, Zemskova M, Linderman JD, Smith S, Drinkard B, et al. (2011) Metabolic Effects of Liothyronine Therapy in Hypothyroidism: A Randomized, Double-Blind, Crossover Trial of Liothyronine Versus Levothyroxine. J Clin Endocrinol Metab 96(11): 3466-3474.

8. Kakucska I, Rand W, Lechan RM (1992) Thyrotropin releasing hormone gene expression in the hypothalamic paraventricular nucleus is dependent upon feedback regulation by both triiodothyronine and thyroxine. Endocrinology 130(5): 2845-2850.

9. Nicoloff JT, Low JC, Dussault JH, Fisher DA (1972) Simultaneous measurement of thyroxine and triiodothyronine peripheral turnover kinetics in man. J Clin Invest 51(3): 473-483.

10. Jonklaas JJ, Bianco AC, Bauer AJ, Burman KD, Cappola AR, et al. (2014) Guidelines for the treatment of hypothyroidism: prepared by the american thyroid association task force on thyroid hormone replacement. Thyroid 24(12): 1670-1751.

11. Goldman JM, Line BR, Aamodt RL, Robbins J (1980) Influence of triiodothyronine withdrawal time on 131I uptake postthyroidectomy for thyroid cancer. J Clin Endocrinol Metab 50(4): 734-739.

12. Escobar-Morreale HF, Botella-Carretero JI, de Escobar GM (2015) Treatment of hypothyroidism with levothyroxine or a combination of levothyroxine plus L-triiodothyronine. Best Best Pract Res Clin Endocrinol Metab 29(1): pp. 57-75.

13. Celi FS, Zemskova M, Linderman JD, Babar NI, Skarulis MC, et al. (2010) The pharmacodynamic equivalence of levothyroxine and liothyronine: a randomized, double blind, crossover study in thyroidectomized patients. Clin Endocrinol 72(5): 709-715.

14. Bunevicius R, Kazanavicius G, Zalinkevicius R, Prange AJ (1999) Effects of thyroxine as compared with thyroxine plus triiodothyronine in patients with hypothyroidism. N Engl J Med 340(6): 424-429.

15. Grozinsky-Glasberg S, Fraser A, Nahshoni E, Weizman A, Leibovici L (2006) Thyroxine-Triiodothyronine Combination Therapy Versus Thyroxine Monotherapy for Clinical Hypothyroidism: Meta-Analysis of Randomized Controlled Trials. J Clin Endocrinol Metab 91(7): 25922599.

16. Nygaard B, Jensen EW, Kvetny J, Jarløv A, Faber J, et al. (2009) Effect of combination therapy with thyroxine (T4) and 3,5, 30-triiodothyronine versus T4 monotherapy in patients with hypothyroidism, a doubleblind, randomised cross-over study. Eur J Endocrinol 161(6): 895-902.

17. Biondi B, Wartofsky L (2011) Combination Treatment with T4 and T3: Towards Personalized Replacement Therapy in Hypothyroidism. J Clin Endocrinol Metab 97(7): 2256-2271.

18. Wilmar M, Duntas L, Fadeyev V, Nygaard B, Vanderpump MP (2012) 2012 ETA Guidelines: The Use of L-T4 + L-T3 in the Treatment of Hypothyroidism. Eur Thyroid J 1(2): 55-71. 
19. Biondi B, Wartofsky L (2012) Combination Treatment with T4 and T3: Toward Personalized Replacement Therapy in Hypothyroidism? J Clin Endocrinol Metab 97(7): 2256-2271.

20. Michaelssona LF, Medici BB, la Cour JL, Selmer C1, Røder M, et al. (2015) Treating Hypothyroidism with Thyroxine/ Triiodothyronine
Combination Therapy in Denmark: Following Guidelines or Following Trends? Eur Thyroid J 4(3): 174-180.

21. Harrison's Principles of Internal Medicine (2012) Disorders of Thyroid glands. (12 $\left.{ }^{\text {th }} e d n\right)$, pp. 2918-2919.

Your next submission with Juniper Publishers will reach you the below assets

- Quality Editorial service

- Swift Peer Review

- Reprints availability

- E-prints Service

- Manuscript Podcast for convenient understanding

- Global attainment for your research

- Manuscript accessibility in different formats

(Pdf, E-pub, Full Text, Audio)

- Unceasing customer service

Track the below URL for one-step submission https://juniperpublishers.com/online-submission.php 